\title{
Epidemiological Profile of Pregnant Women with Eclampsia Admitted in Cuiabá Hospitals from 2008 to 2017
}

\section{Perfil de Internações de Gestantes Acometidas com Eclampsia no Município de Cuiabá no Período de 2008 a 2017}

\author{
Alissa Cristina de Oliveira ${ }^{a}$; Bruna Cararo Machado ${ }^{a}$; Camila Félix De Oliveira ${ }^{\text {; }}$ Fabiana Canavarros Correa de Arruda \\ Schneider ${ }^{a}$; Frederico César Caixeta ${ }^{a}$; Giovana Silva Martinss; Mariana Almeida Pereira ${ }^{\text {a }}$; Ageo Mario Cândido da \\ Silva*b
}

\author{
a'University of Cuiabá, Course of Medicine. MT, Brazil. \\ bUniversity of Cuiabá, Stricto Sensu Graduate Program in Environment and Health. MT, Brazil. \\ *E-mail. ageoms@hotmail.com \\ Recebido em: 25/04/2019; Aprovado em: 30/08/2019
}

\begin{abstract}
During pregnancy, women undergo several physiological body changes. However, there are some pathologies that can interfere in this period. In Brazil, the main cause of maternal mortality stems from hypertensive disorders. The increased blood pressure gestational period may be due to a preexisting chronic hypertension or Gestational hypertension. Therefore, the hypertension during pregnancy may evolve to preeclampsia, eclampsia or HELLP Syndrome. Each of these disorders has consequences for the mother and the fetus, which can be fatal, in the most serious cases. The objective of this study is to recognize the profile of pregnant women hospitalized with eclampsia, whereas the knowledge of the signs that the pathology presents and the most frequent epidemiological profile to help in the early diagnosis, which directly impacts on the efficacy of the treatment, reducing morbidity and mortality. This study aimed to evaluate the information available in the Sistema de Internações Hospitalares (SIH) of the Sistema de Informações da Secretaria do Estado de Saúde de Mato Grosso and to analyze the increase of pregnant women with eclampsia, in addition to the epidemiological profile of this group. After analyzing the data, it was verified that AfroBrazilian women, aged between 20-24 years old, are the most affected by eclampsia. In addition, most cases have been reported by private hospitals and more than 50 percent remain hospitalized for up to 3 days. Despite the limitations in the database, the recognition of the most frequent conditions during hospitalization contributes to a better approach to these cases.
\end{abstract}

Keywords: Risk Factors. Pregnancy Hospital Information System - HIS/SUS.

\section{Resumo}

Durante o periodo gestacional, a mulher passa por diversas mudanças fisiológicas. Entretanto, existem algumas patologias que podem interferir nesse periodo. No Brasil, a principal causa de mortalidade materna decorre das síndromes hipertensivas. O aumento dos niveis pressóricos na gravidez pode ser originada por hipertensão crônica prévia ou pela Doença Hipertensiva Especifica da Gestação (DHEG). Sendo que, essa última pode evoluir para pré-eclâmpsia, eclampsia ou Síndrome HELLP. Cada uma dessas variações gera consequências para a mãe e o feto, podendo levar à morte, nos casos mais graves. O objetivo desse trabalho é reconhecer o perfil de internações das gestantes acometidas com eclâmpsia, uma vez que o conhecimento dos sinais que a patologia apresenta e o perfil epidemiológico mais frequente auxiliam na identificação precoce dos casos, o que impacta diretamente na eficácia do tratamento, reduzindo a morbimortalidade. Esse estudo, buscou avaliar informações disponíveis no Sistema de Internações Hospitalares (SIH) do Sistema de Informações da Secretaria do Estado de Saúde de Mato Grosso e analisar, por meio deste, a progressão das gestanteacometidas com eclampsia, além do perfil epidemiológico desse grupo. Após a análise das informações, verificou-se que as mulheres afro brasileiras, com idade entre 20 e 24 anos, são as mais acometidas pela patologia em estudo. Além disso, a maioria dos casos, foram notificados por hospitais particulares e mais da metade, permanece internada por até 3 dias. Apesar das limitações presentes no banco de dados, o reconhecimento das características mais frequentes durante a internação, contribui para uma melhor abordagem desses casos.

Palavras-chave: Fatores de Risco. Gravidez. Sistema de Informações Hospitalares.

\section{Introduction}

The hypertensive syndromes in pregnancy are in the scenario of public health, representing the third obstetric cause of death worldwide and the first in Brazil. In developed countries, approximately two to eight in every 100 pregnant women will develop the disease, whereas in Brazil it can reach $10 \%$ of the cases ${ }^{1}$. Due to the severity of the disease, is considered one of the most significant health problems in pregnancy, resulting in high rates of hospitalization in intensive care unit and, sometimes, included as a criterion of severe maternal morbidity ${ }^{2}$.

These syndromes, according to time of emergence and its relationship with the pregnancy, presence of proteinuria and severity of the condition, are classified as chronic hypertension, gestational hypertension, pre-eclampsia and eclampsia alone or superimposed ${ }^{1}$. Chronic hypertension is characterized by high pressure before the 20th week of gestation, having no relationship with the state of pregnancy ${ }^{3}$. The specific hypertensive disease of pregnancy (HDP) is an obstetrical pathology that comes after this gestational age, being more frequent in the third quarter and extending to the puerperium, which can evolve as pre-eclampsia ${ }^{4}$.

Pre-eclampsia is described as a multisystemic disease of pregnancy and is characterized by clinical and laboratory 
manifestations from the second half of pregnancy, due to the increase of blood pressure levels in a pregnant patient, previously normotensive, resulting in hypertension, edema and proteinuria ${ }^{5}$. When accompanied by seizures is called eclampsia ${ }^{6}$.

The present study aimed to carry out an analysis of the profile of admissions of pregnant women affected with eclampsia in the municipality of Cuiabá, in the period from 2008 to 2017, with the aim of assessing the interconnected characteristics, events related to the hospitalization and its particularities.

\section{Material and Methods}

Research of Quantitative and descriptive approach with data from the system of hospital admissions (SIH) available in the Information System of the Secretariat of the state of health of Mato Grosso (DwWebSES-MT). The inclusion criteria were pregnant women (ICD 10), ranging in age from 10 to 59 years, all ethnicities/races. The exclusion criterion was pregnant women with pre-eclampsia (ICD 10 O14). The research protocol used is presented in Table 1.

Table - Research Protocol

\begin{tabular}{|l|c|}
\hline Selected Theme & Admissions \\
\hline Selected Filters & 2007/2008/2009/2010/2011/2012/2 \\
Year of hospitalization & $013 / 2014 / 2015 / 2016 / 2017$ \\
Code of the municipality & 510340 (Cuiabá) \\
\hline & Days of permanence \\
Complexity \\
Diagnosis condition sensitive to \\
primary health \\
Main Diagnosis \\
Selections defined & Main diagnosis ICD (Chapter) \\
& Ethnicity \\
& Age Range \\
Death \\
Hospital Corporate Name \\
Age \\
Permanence days \\
Race Color \\
Sex \\
Remained in ICU \\
STATE Residence \\
\hline
\end{tabular}

Source: Research Data.

The data analysis followed the following hypotheses: 1) Afro-Brazilian women (independent variable) have a higher risk of developing eclampsia (dependent variable); 2) women who have eclampsia (independent variable) have a higher risk remain to stay longer hospitalized (dependent variable); 3) women who have eclampsia (independent variable), there is a higher risk of death (dependent variable); 4) women who have eclampsia (independent variable) have a higher risk of being forwarded to ICU (dependent variable) and 5) Women in the age range of risk (independent variable) have a higher risk of developing eclampsia (dependent variable).

According to the Resolution 466/2012, it is considered that all research involving humans directly or indirectly, involves risks, whether actual or potential. Due to being data analysis in the public domain of unrestricted access of DwWebSESMT where personal data are not informed of the records, according to the Resolution 510/2016, Law No. 12.527/2011, the submission of this survey to assess the system CEPCONEP was not required .

\section{Results and Discussion}

In the analyzed period (2008-17), 29,225 hospitalizations with a main diagnosis of eclampsia in pregnancy, childbirth and the puerperium were recorded in Cuiabá. The analysis of the records indicated that the predominant characteristics of the cases were private hospital system (83.7\%), a period of hospitalization until 3 days $(73.8 \%)$, the age range of 20-29 years (49.6\%), afros brasileiras (93.37\%), with ICU admissions and deaths relatively low $(<1 \%)$ (Table 2$)$.

Table 2 - Characterization of the second hospital admissions scheme, hospitalization period, age, ethnicity, hospitalization in the ICU and deaths in Cuiabá, 2008-2017

\begin{tabular}{|c|c|c|}
\hline Variable & Number & $\%$ \\
\hline $\begin{array}{c}\text { Hospital Regime } \\
\text { Public } \\
\text { Private } \\
\text { Total }\end{array}$ & $\begin{array}{c}4762 \\
24462 \\
\mathbf{2 9 2 2 4}\end{array}$ & $\begin{array}{c}16.28 \\
83.71 \\
\mathbf{1 0 0 . 0 0}\end{array}$ \\
\hline $\begin{array}{c}\text { Period of Hospitalization } \\
\text { Up to } 3 \text { days } \\
\text { 4 days or more } \\
\text { Total } \\
\end{array}$ & $\begin{array}{c}21576 \\
7648 \\
\mathbf{2 9 2 2 4} \\
\end{array}$ & $\begin{array}{c}73.83 \\
26.17 \\
\mathbf{1 0 0 . 0 0} \\
\end{array}$ \\
\hline $\begin{array}{c}\text { Age Range } \\
10 \text { to } 14 \text { years } \\
15 \text { to } 19 \text { years } \\
20 \text { to } 24 \text { years } \\
25 \text { to } 29 \text { years } \\
30 \text { to } 34 \text { years } \\
35 \text { to } 39 \text { years } \\
40 \text { to } 44 \text { years } \\
45 \text { to } 49 \text { years } \\
50 \text { to } 54 \text { years } \\
55 \text { to } 59 \text { years } \\
\text { Total }\end{array}$ & $\begin{array}{c}495 \\
5299 \\
7585 \\
6910 \\
5050 \\
2889 \\
907 \\
81 \\
6 \\
2 \\
\mathbf{2 9 2 2 4} \\
\end{array}$ & $\begin{array}{c}1.69 \\
18.13 \\
25.95 \\
23.64 \\
17.28 \\
9.89 \\
3.10 \\
0.28 \\
0.02 \\
0.01 \\
\mathbf{1 0 0 . 0 0}\end{array}$ \\
\hline $\begin{array}{c}\text { Ethnicity } \\
\text { Afro Brazilian } \\
\text { Others } \\
\text { Total } \\
\end{array}$ & $\begin{array}{c}27286 \\
1938 \\
\mathbf{2 9 2 2 4} \\
\end{array}$ & $\begin{array}{c}93.37 \\
6.63 \\
\mathbf{1 0 0 . 0 0} \\
\end{array}$ \\
\hline $\begin{array}{c}\text { Admission to an ICU } \\
\text { No } \\
\text { Yes } \\
\text { Total } \\
\end{array}$ & $\begin{array}{c}28951 \\
273 \\
\mathbf{2 9 2 2 4} \\
\end{array}$ & $\begin{array}{c}99.07 \\
0.93 \\
\mathbf{1 0 0 . 0 0}\end{array}$ \\
\hline $\begin{array}{c}\text { Deaths } \\
\text { No } \\
\text { Yes } \\
\text { Total } \\
\end{array}$ & $\begin{array}{c}29203 \\
21 \\
\mathbf{2 9 2 2 4}\end{array}$ & $\begin{array}{c}99.93 \\
0.07 \\
\mathbf{1 0 0 . 0 0}\end{array}$ \\
\hline
\end{tabular}

Source: Research Data.

The admissions with a diagnosis of eclampsia corresponded to less than $1 \%$, being $95.5 \%$ afro Brazilian, $91.4 \%$ of women with age below 34 years (mainly between 20-24; 34.4\%) (Figure 1), 58\% admitted until 3 days 12.1\% with ICU admission and less than $<1 \%$ progressed to death. 
Figure 1 - Age range with eclampsia

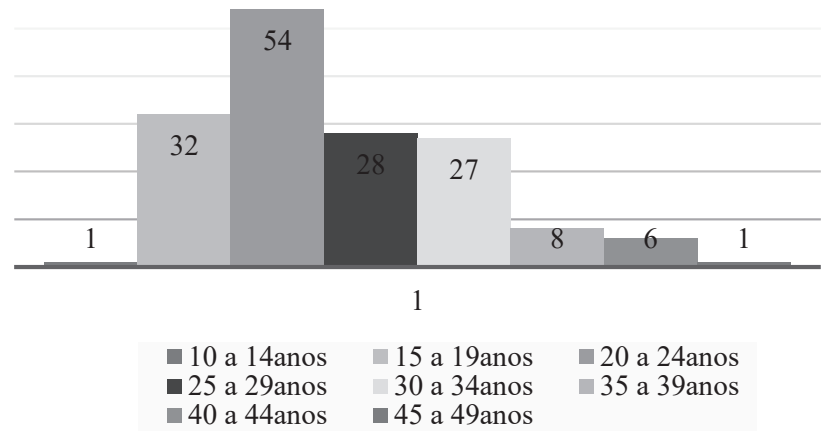

Source: Research Data.

From the bivariate analyzes with demographic data it is possible to perceive that the risk of an Afro Brazilian to have eclampsia is 1.5 times greater than white women $(95 \%$ $\mathrm{CI}=0.7143-3.2430)$. In the analysis, the patient that has eclampsia has 2 times more risk of remaining hospitalized for more than 4 days than the other pregnant women $(95 \% \mathrm{CI}=$ 1.4920 - 2.8060) and had 9 times more risk of death $(95 \%$ $\mathrm{CI}=1.25$ - 68.5559). Patients who present eclampsia have approximately 14 times more risk of being forwarded to ICU $(95 \% \mathrm{CI}=8.9283-21.4819)$. In addition, the age group at risk showed a non-significant risk of 1.12 times greater chance of presenting eclampsia $(95 \% \mathrm{CI}=0.7897$ - 1.6157).

The patients hospitalization profile who have eclampsia, has a poor prognosis within the hypertensive syndromes in pregnancy, reveals that the predisposing factors are intimately linked with the hospitalization of these women. In this sense, one of the characteristics of risk is the age range that comprises from 20 to 29 years, which has a greater chance of developing the disease and represents $49.6 \%$ of the affected population. This occurs due to the period in which women are more prone to get pregnant, in comparison with the age of the beginning and end of fertility, which exhibit lower values as described above.

In relation to the time of hospitalization, in women diagnosed with eclampsia present higher hospitalization period in relation to other pregnant women. Within these, it was identified that the afro-Brazilian are two times more likely to remain hospitalized up to four days, in comparison with other ethnic groups. In addition, they also have a higher risk of developing this hypertensive syndrome, our data suggest that are $50 \%$ higher chance of an Afro-Brazilian woman having eclampsia, corroborate with the literature.

From the severity of hypertensive disease, those involved have 14 times greater risk of being forwarded to the Intensive Care Unit (ICU) equated to pregnant women without complications, although correspond only to $12.1 \%$ of admissions. Even though signals are critical, less than $1 \%$ of women with eclampsia evolve to death, being that the Afro-Brazilian have nine times greater prevalence of death compared with other ethnic groups.

\section{Conclusion}

The study allowed us to characterize the profile of pregnant women with eclampsia hospitalized in the city of Cuiabá, in the period from 2008 to 2017, relating the racial characteristics and age with race characteristic and period of hospitalization. It can be concluded that there is a predominance in AfroBrazilian women and in the age range from 20-29 years; and that the delineation of hospitalization is marked by particular hospital regime and period of stay for up to 3 days.

Certain limitations were found, because the data source is secondary, and the information collected is from a database provided by the Health Department of the state of Mato Grosso. Thus, some information that would complement the study, such as for example the beginning of the pre-natal, were not part of the data provided. Another point is due to the point that, in fact, our study was retrospective, thus hindering the direct contact of the researchers with the investigated women.

It is considered that characterizing the profile of pregnant women is of extreme relevance to diagnose and minimize the complications arising from eclampsia, because it contributes to the identification of risks and with that the elaboration of preventive strategies aiming at the reduction of injuries and enabling the provision of a quality care.

\section{References}

1. Amorim MMR, Katz L, Miranda GVSJ. Perfil clínico, laboratorial e complicações de pacientes com síndrome HELLP admitidas em uma unidade de terapia intensiva obstétrica. Rev Bras Ginecol Obs 2008;30(2):82-6 doi: 10.1590/S0100-72032008000200006

2. Orcy RB, Pedrini RO, Piccinini PS, Schroeder SS, Costa SHAM, Ramos JGL, Capp E, Corleta HVE. Diagnóstico, fatores de risco e patogênese da pré-eclâmpsia. Rev HCPA 2007;27(3):43-6.

3. Kahhale S, Francisco RPV, Zugaib M. Pré-eclampsia. Rev Med 2018;97(2):226-34. doi: http://dx.doi.org/10.11606/ issn.1679-9836.v97i2p226-234

4. Peixoto MV, Martinez MD, Valle NSB. Síndromes hipertensivas na gestação: estratégia e cuidados de enfermagem. Rev Edu Meio Amb Saúde 2008;3(1):208-22.

5. Almeida KBDE, Neves LA. Pré-eclâmpsia: uma revisão de literatura nacional. Batatais: Centro Universitário Claretiano; 2006.

6. Carmo WR, Carvalho TR, Costa RS, Ferreira GG, Kussler IE, Maduro RV, Souza SF, Martins VD, Schneider WC. Eclâmpsia: abordagem ao diagnóstico e à conduta. Rev Méd. Minas Gerais 2008;18(3 Supl 4):25-8. 